\title{
Different desulfurizer removal of total sulfur from coal
}

\author{
Zhang Yanmin Shan Jianfa \\ College of Chemistry and Chemical Engineering, Longdong University, \\ Qingyang 745000, China
}

\begin{abstract}
This article mainly introduced the desulfurization effect of different desulfurizer on coal under the same condition. The results showed that: in the single metal oxide desulfurizer, $\mathrm{CaO}$ desulfurization effect is obviou; the compound desulfurizer $\mathrm{ZnO}-\mathrm{CaO}$ desulfurization effect is best, and the two classes of desulfurizer has a synergistic effect, cooperate to use can enhance the removal effect of sulfur in coal.

Key words: coal desulfurization, coulomb titration method, desulfurizer

Sulfur in coal is a harmful element in the process of combustion and coking, coal desulfurization problems have been closely watched. The distribution of sulfur content in coal in our country presents the trend of "south more north less", low sulfur coal focuses in the northeast and north China, high sulfur coal focuses in south China and east China provinces ${ }^{[1]}$. There are many methods of coal pre combustion desulfurization, which can be divided into physical desulfurization method, chemical desulfurization method, biological desulfurization method and electrochemical desulfurization method. The desulfurization of coal is closely related to the occurrence state of sulfur in coal, and the occurrence form of sulfur in coal is very complex, mainly including inorganic sulfur and organic sulfur, sometimes including trace element sulfur in monomer state. Organic sulfur exists in the molecular structure of coal by mercaptan or hydroxyl compounds, sulfides, disulfide and thiophene of the functional groups ${ }^{[2,3]}$. Inorganic sulfur mainly exists in the form of sulfide, there are a small amount of sulfur in sulfate, inorganic sulfur minerals dominated by pyrite, sulfate in calcium, iron, magnesium and barium sulfate form ${ }^{[4]}$. Organic sulfur in coal is part of the organic matter in coal, together with organic structure and organic bond in coal, it is difficult to remove by washing ${ }^{[5]}$. Understanding sulfur content in coal is great significance to control the harmful effects of sulfur. For power coal, if the
\end{abstract}


high sulfur content, $\mathrm{SO}_{2}$ produced during the combustion of coal not only pollute the atmosphere, but also corrosion of boiler pipeline, $\mathrm{SO}_{2}$ or nitrogen oxide causes acid rain and has a direct impact on agricultural production; for coking, the total sulfur content is high, about $80 \%$ of the total sulfur in coal into coke, causing a large amount of sulfur in the steelmaking process into steel, made out of steel brittle. Now advocate green coal, sulfur as a harmful substance, has become an important index of evaluation of coal quality. In order to utilize coal resource economically and effectively, it is necessary to know the true content of sulfur in coal. Therefore, the determination of sulfur in coal is great significance both in industry and coal quality research. At present, the method of determination of total sulfur in coal, the coulomb titration method has the advantages of fast determination speed, accurate determination result, simple operation and so on. The coulomb titration is the most widely used method. In this paper, the effect of adding desulfurizer on the removal of sulfur from coal was studied by coulomb titration ${ }^{[6]}$.

\section{Experimental part}

Color silicone, ice acetic acid, $\mathrm{CaO}, \mathrm{ZnO}, \mathrm{Fe}_{2} \mathrm{O}_{3}, \mathrm{WO}_{3}, \mathrm{KI}, \mathrm{KBr}$; coulomb integrator.

The coal of Ningxia Wangwa was selected as the research object and crushed to 180-200 mesh.

The coal samples are burned at $1150^{\circ} \mathrm{C}$ under the action of catalyst in the air stream, the various forms of sulfur in the coal are oxidized and decomposed into $\mathrm{SO}_{2}$ and $\mathrm{SO}_{3}$. In the electrolysis of $\mathrm{KI}-\mathrm{KBr}$ solution to produce iodine and bromine oxidation titration $\mathrm{SO}_{2}$. Calculation of total sulfur content in coal based on the amount of electricity consumed by iodine and bromine.

The specific reaction process is as follows:

Sulfur in coal $+\mathrm{O}_{2} \rightarrow \mathrm{CO}_{2}+\mathrm{H}_{2} \mathrm{O}+\mathrm{SO}_{2}+\mathrm{Cl}_{2}+\ldots \ldots$.

$4 \mathrm{FeS}_{2}+11 \mathrm{O}_{2} \rightarrow 2 \mathrm{Fe}_{2} \mathrm{O}_{3}+8 \mathrm{SO}_{2}$

$\mathrm{MSO}_{4} \rightarrow \mathrm{MO}+\mathrm{SO}_{2}+\mathrm{O}_{2}+(\mathrm{M}$ refers to metal elements)

$2 \mathrm{SO}_{2}+\mathrm{O}_{2} \rightarrow 2 \mathrm{SO}_{3}$ flow,

The generation of $\mathrm{SO}_{2}$ and $\mathrm{SO}_{3}$ are brought into the electrolytic cell by air

and combined with water generating sulfurous acid and small amounts of sulfuric acid. The electrolytic cell is equipped with $\mathrm{KBr}$ and $\mathrm{KI}$ solution, two pairs of platinum electrodes, one pair is indicating electrodes, and one pair is electrolytic electrodes.

Before the sulfur oxide enters the electrolytic cell, the following dynamic balance exists on the indicating electrodes:

$2 \mathrm{I}^{-}-2 \mathrm{e} \rightarrow \mathrm{I}_{2}$

$2 \mathrm{Br}^{-}-2 \mathrm{e} \rightarrow \mathrm{Br}_{2}$

When $\mathrm{SO}_{2}$ enters the solution, it will react with iodine and bromine:

$\mathrm{I}_{2}+\mathrm{SO}_{2}+\mathrm{H}_{2} \mathrm{O} \rightarrow 2 \mathrm{I}^{-}+\mathrm{SO}_{3}{ }^{2-}+2 \mathrm{H}^{+}$ 
$\mathrm{Br}_{2}+\mathrm{SO}_{2}+\mathrm{H}_{2} \mathrm{O} \rightarrow 2 \mathrm{Br}^{-}+\mathrm{SO}_{3}{ }^{2-}+2 \mathrm{H}^{+}$

At this time, the dynamic balance is destroyed, the potential of the indicating electrode pair changes, which causes the electrolytic current to increase, electrolyzes iodine and bromine continuously, until there is no $\mathrm{SO}_{2}$ into the solution, electrode potential returns to the level before titration, electrolytic iodine and bromine behavior stops. At this point, the total sulfur content in coal can be calculated according to the consumption of electricity by iodine and bromine.

Weigh $5 \mathrm{~g}$ analysis of pure $\mathrm{KI}, 5 \mathrm{~g}$ analysis of pure $\mathrm{KBr}$, add $10 \mathrm{ml}$ ice acetic acid plus $250 \mathrm{ml}$ water, after dissolving and stirring evenly. The prepared electrolyte should be put into the brown bottle.

The determination of total sulfur in coal samples are recommended in the GB/T 214-2007 of coulomb titration method ${ }^{[7]}$, the measured results of sulfur content are shown in table 1.

Table 1 sulfur content in coal samples

\begin{tabular}{lcc}
\hline serial number & coal samples $(\mathrm{g})$ & sulfur content $(\%)$ \\
\hline $1 \#$ & 0.0523 & 0.915 \\
$2 \#$ & 0.0523 & 0.907 \\
\hline
\end{tabular}

\section{Results and discussion}

$\mathrm{CaO} 、 \mathrm{ZnO} 、 \mathrm{Fe}_{2} \mathrm{O}_{3} 、 \mathrm{CaO}-\mathrm{ZnO} 、 \mathrm{CaO}-\mathrm{Fe}_{2} \mathrm{O}_{3} 、 \mathrm{ZnO}-\mathrm{Fe}_{2} \mathrm{O}_{3}$ was selected as desulfurizer in turn. The corresponding experimental results are shown in Table 2 and Figure 1. 
Table 2 desulfurizer desulfurization efficiency (\%)

\begin{tabular}{|c|c|c|c|c|c|}
\hline desulfurizer : coal samples & $1: 10$ & $3: 10$ & $5: 10$ & $7: 10$ & $9: 10$ \\
\hline $\mathrm{CaO}$ & 0.772 & 0.618 & 0.469 & 0.348 & 0.299 \\
\hline $\mathrm{ZnO}$ & 0.917 & 0.724 & 0.704 & 0.686 & 0.601 \\
\hline $\mathrm{Fe}_{2} \mathrm{O}_{3}$ & 0.911 & 0.877 & 0.874 & 0.699 & 0.867 \\
\hline $\mathrm{CaO}-\mathrm{ZnO}$ & 0.748 & 0.580 & 0.550 & 0.509 & 0.100 \\
\hline $\mathrm{CaO}-\mathrm{Fe}_{2} \mathrm{O}_{3}$ & 0.789 & 0.772 & 0.720 & 0.668 & 0.778 \\
\hline $\mathrm{ZnO}-\mathrm{Fe}_{2} \mathrm{O}_{3}$ & 0.912 & 0.901 & 0.962 & 0.749 & 0.886 \\
\hline
\end{tabular}

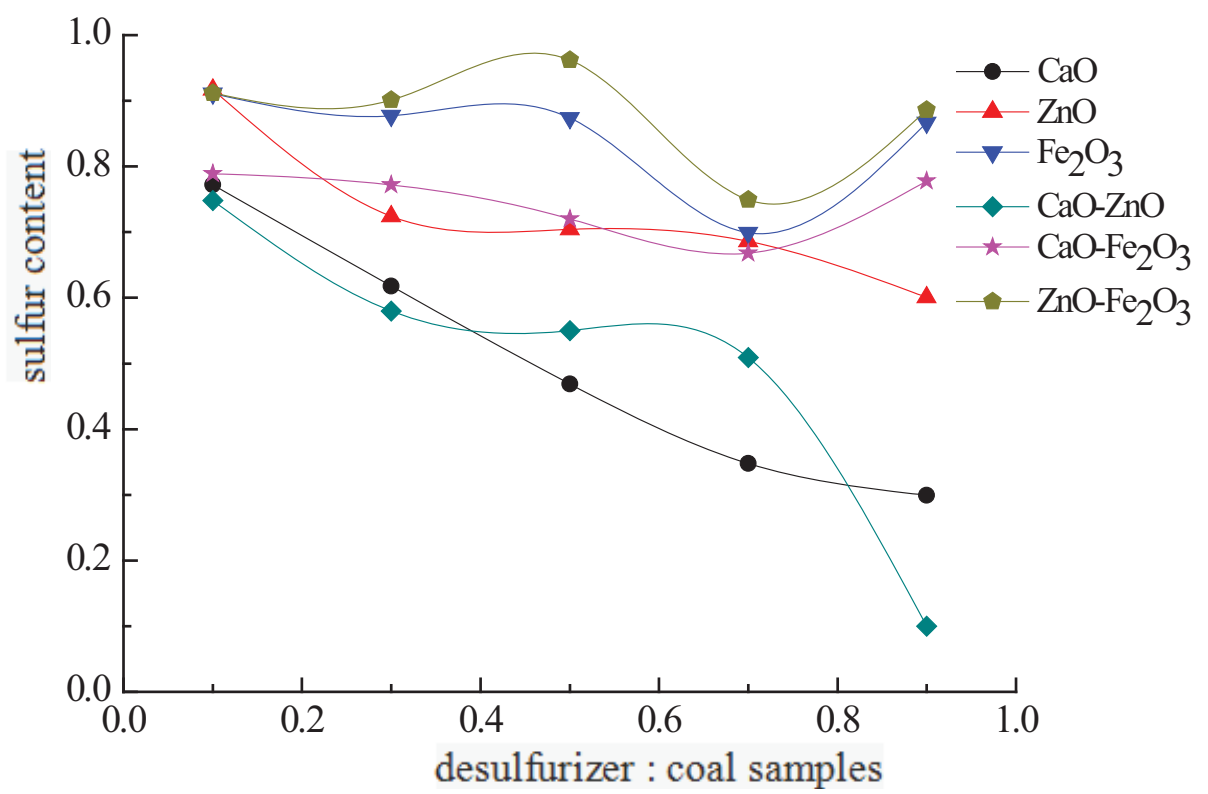

Figure 1 desulfurizer desulfurization efficiency curve 
It can be seen from Table 2 and Figure 1 that the removal efficiency of sulfur by single desulfurizer $\mathrm{CaO}$ is the most obvious, and the desulfurization efficiency increases with the increase of desulfurizer content. The mechanism of $\mathrm{CaO}$ is as follows:

$$
\begin{gathered}
\mathrm{CaO}+2 \mathrm{H}_{2} \mathrm{O} \rightarrow \mathrm{Ca}(\mathrm{OH})_{2} \\
\mathrm{Ca}(\mathrm{OH})_{2}+\mathrm{CO}_{2} \rightarrow \mathrm{CaCO}_{3}+\mathrm{H}_{2} \mathrm{O} \\
\mathrm{CaCO}_{3}+\mathrm{SO}_{2} \rightarrow \mathrm{CaSO}_{3}+\mathrm{CO}_{2} \\
\mathrm{CaSO}_{3}+1 / 2 \mathrm{O}_{2} \rightarrow \mathrm{CaSO}_{4}
\end{gathered}
$$

$\mathrm{CaO}$ desulfurization process can be divided into the following steps, mainly absorption, neutralization, oxidation, crystallization, although the reaction steps are expressed in turn, but the actual desulfurization process is carried out simultaneously. Calcium oxides are generally used for high temperature desulfurization, especially

for the desulfurization of fuel coal. The absorption of $\mathrm{SO}_{2}$ in the process of

desulfurization can be divided into physical absorption and chemical absorption.

Separately adopting physical absorption, because of its low purification efficiency, it is difficult to achieve $\mathrm{SO}_{2}$ emission standards, so the chemical absorption has been widely used in the desulfurization technology. The chemical absorption rate is much larger than the physical absorption rate.

$\mathrm{ZnO}$ can not only remove inorganic sulfur, but also remove organic sulfur. It has the advantages of high desulfurization precision, large sulfur capacity, stable and reliable performance. The main drawback of $\mathrm{ZnO}$ desulfurizer is that it can not be regenerated by oxidation and new adsorbent should be replaced. Therefore, the surface of the regeneration adsorbent will be obviously reduced by sintering. Mechanical strength is greatly reduced, and $\mathrm{ZnO}$ use higher $\operatorname{cost}^{[8]}$.

The sulfur removal efficiency of $\mathrm{Fe}_{2} \mathrm{O}_{3}$ is lower, and the desulfurization efficiency first increases and then decreases with the increase of desulfurizer content;

$\mathrm{Fe}_{2} \mathrm{O}_{3}$ desulfurizer is a kind of desulfurizer with active iron oxide $\left(\mathrm{Fe}_{2} \mathrm{O}_{3}\right)$ hydrate as main desulfurization component. At normal temperature, iron oxide $\left(\mathrm{Fe}_{2} \mathrm{O}_{3}\right)$ is divided into a-hydrate and $\gamma$-hydrate, and the two kinds of hydrate have desulfurization effect.

Non - hydrate iron oxide does not have desulfurization effect at room temperature.

$\mathrm{Fe}_{2} \mathrm{O}_{3}$ desulfurizer and $\mathrm{H}_{2} \mathrm{~S}$ act and release heat, according to the different hydration properties of iron oxide, resulting in different forms of reaction as follows:

$$
\begin{array}{lr}
\mathrm{Fe}_{2} \mathrm{O}_{3} \cdot \mathrm{H}_{2} \mathrm{O}+3 \mathrm{H}_{2} \mathrm{~S} \rightarrow \mathrm{Fe}_{2} \mathrm{~S}_{3} \cdot \mathrm{H}_{2} \mathrm{O}+3 \mathrm{H}_{2} \mathrm{O} & \Delta \mathrm{H}=-63 \mathrm{KJ} / \mathrm{mol} \\
\mathrm{Fe}_{2} \mathrm{O}_{3} \cdot \mathrm{H}_{2} \mathrm{O}+3 \mathrm{H}_{2} \mathrm{~S} \rightarrow 2 \mathrm{FeS}+\mathrm{S}+4 \mathrm{H}_{2} \mathrm{O} & \Delta \mathrm{H}=-103 \mathrm{KJ} / \mathrm{mol}
\end{array}
$$

$\mathrm{FeS}$ and $\mathrm{Fe}_{2} \mathrm{~S}_{3}$ react under aerobic conditions and at appropriate temperatures to produce the following reduction reaction and release heat. This is also the reason $\mathrm{Fe}_{2} \mathrm{O}_{3}$ desulfurization efficiency is low.

$\mathrm{Fe}_{2} \mathrm{~S}_{3} \cdot \mathrm{H}_{2} \mathrm{O}+3 / 2 \mathrm{O}_{2} \rightarrow \mathrm{Fe}_{2} \mathrm{O}_{3} \cdot \mathrm{H}_{2} \mathrm{O}+3 \mathrm{~S}$

$2 \mathrm{FeS} \cdot \mathrm{H}_{2} \mathrm{O}+2 \mathrm{O}_{2} \rightarrow \mathrm{Fe}_{2} \mathrm{O}_{3} \cdot \mathrm{H}_{2} \mathrm{O}+2 \mathrm{~S}+\mathrm{H}_{2} \mathrm{O}$ 
For composite desulfurizer $\mathrm{CaO}-\mathrm{ZnO}$, the removal of sulfur in coal is mainly using calcium, zinc oxide reaction with $\mathrm{H}_{2} \mathrm{~S}$. Chemical reaction is:

$\mathrm{CaO}+\mathrm{ZnO}+2 \mathrm{H}_{2} \mathrm{~S} \rightarrow \mathrm{ZnS}+\mathrm{CaS}+2 \mathrm{H}_{2} \mathrm{O}$

By a certain amount of calcium, zinc oxide and coal after drying treatment, adding high temperature furnace reaction to generate $\mathrm{CaS}, \mathrm{ZnS}$. In this process, $\mathrm{CaO}, \mathrm{ZnO}$ is both desulfurization and has a certain catalytic effect. The use of the two desulfurizer can not only increase the desulfurization efficiency, but also improve the mechanical strength of the desulfurizer.

The desulfurization principle of $\mathrm{CaO}-\mathrm{Fe}_{2} \mathrm{O}_{3}$ is simple because the $\mathrm{CaO}$ and $\mathrm{SO}_{2}$ reaction, the surface of $\mathrm{CaO}$ grain into $\mathrm{CaSO}_{4}$, and expansion. A dense reaction product layer was generated, which hindered the diffusion of $\mathrm{SO}_{2}$ into the deep particles and further sulfate reaction. The addition of iron oxide particles causes the $\mathrm{CaO}$ to be continuously activated as the active center and vulcanization during the $\mathrm{CaO}$ transformation process. At the same time, the microscopic pore structure of the surface layer and the near surface layer is greatly changed, the migration and recombination of the grains are produced. In addition, dense product layer was not formed, which created conditions for further sulfur fixation reaction and deep expansion reaction. Under certain temperature conditions, $\mathrm{SO}_{2}, \mathrm{O}_{2}$ and other gases migrated from $\mathrm{Fe}_{2} \mathrm{O}_{3}$ to $\mathrm{CaO}$, while $\mathrm{Fe}_{2} \mathrm{O}_{3}$ in $\mathrm{Fe}$ migrated to $\mathrm{CaO}$ (for example : $\left.\mathrm{CaO}+\mathrm{Fe}_{2} \mathrm{O}_{3} \rightarrow \mathrm{CaFeO}_{2}\right)^{[9]}$, which improved the reaction activity.

For the compound desulfurizer $\mathrm{ZnO}-\mathrm{Fe}_{2} \mathrm{O}_{3}$, its desulfurization efficiency has not changed obviously. The main reason is that $\mathrm{ZnO}$ is not stable in the condition of high temperature, easy to decompose into elemental zinc volatilization, and $\mathrm{Fe}_{2} \mathrm{O}_{3}$ must be hydrate form to have desulfurization effect. So the desulfurization effect of the composite desulfurizer is not obviously changed.

\section{Conclusion}

(1) Under the condition of single desulfurizer, the removal efficiency of $\mathrm{CaO}$ and $\mathrm{ZnO}$ sulfur in coal is obvious, and the desulfurization efficiency increases with the increase of desulfurizer content. The reason is that $\mathrm{CaO}$ and $\mathrm{ZnO}$ can react with $\mathrm{S}$ in coal to produce stable compounds, but the mechanical strength of $\mathrm{ZnO}$ is low and the use cost is higher.

(2) The desulfurization efficiency of $\mathrm{Fe}_{2} \mathrm{O}_{3}$ at high temperature is low, the main reason is that $\mathrm{Fe}_{2} \mathrm{O}_{3}$ must be hydrate form to have desulfurization effect.

(3) In the compound desulfurizer, the application of $\mathrm{CaO}-\mathrm{ZnO}$ can enhance the removal effect of sulfur in coal. The two kinds of desulfurizer have synergistic effect. On the one hand the compound desulfurizer increased the mechanical strength of desulfurizer, on the other hand it reduced the cost of use.

\section{Acknowledgment}

Fund Project: Gansu provincial key discipline construction projects of Applied 
Chemistry (No. GSKS201304AC ).

\section{Reference}

[1] Luo Yunfei, Li Wenhua, Jiang Ying etc. Distribution of sulfur in coals of China[J].

Coal conversion, 2005, 28(3): 14-18.

[2] Zhong Yunying, Guan Mengpin, Cui Kairen etc. Coal chemistry[M]. Xu zhou: China mining university press, 1989:87-88.

[3] Zhao Xinfa, Zhang Guanghua, Yang Liyan. Development of biodesulfurization and simulation of stored-up status of organic sulfur in coal[J]. Coal conversion, 2003, 26(3):16-20.

[4] Dai Shifeng. The formation of sulpher in coal and its control factors[J]. Journal of shandong mining institute, 1996, 15(4):7-11.

[5] Han Yue. Study on effect of various desulfurizer in process of removal sulfur from coal[J]. Coal conversion, 2010, 33(3):56-58.

[6] Zhang Xueying. Determination of total sulfur in coal by coulomb titration method and prospect of removal of organic sulfur in coal[J]. Inner Mongolia Petrochemical Industry, 2013, 3:53-55.

[7] GB/T 214-2007 The determination methods of total sulfur in coal[S].General Administration of quality supervision, inspection and Quarantine of the People's Republic of China, 2008.

[8] Feng $\mathrm{Xu}$. Research trends of $\mathrm{ZnO}$ desulfurizer[J]. Chemical industry and Engineering Technology, 2008, 29(2):31-34.

[9] Li Yanxu etc. Preparation of iron-calcium oxide hot temperature coal gas desulfurizer[J]. Journal of fuel chemistry, 1999, 27(6): 529-534. 